\title{
Pengaruh Ekstrak Daun Ngokilo (Stachytarpheta Mutabilis, Vahl) Terhadap Penyakit Diabetes Mellitus
}

\author{
Kustini $^{1}$, Ida Susila ${ }^{1}$ \\ ${ }^{1,1}$ Diploma III Kebidanan Unversitas Islam Lamongan
}

\begin{abstract}
Abstrak: Diabetes adalah suatu penyakit, dimana tubuh penderitanya tidak bisa mengendalikan tingkat gula (glukosa) dalam darahnya. Penderita diabetes tidak bisa memproduksi insulin dalam jumlah yang cukup atau tubuh yang tak mampu menggunakan insuin secara efektif, sehingga terjadi kelebihan gula di dalam darah. Kelebihan gula yang kronis di dalam darah (hiperglikemia) menjadi racun bagi tubuh. Tanaman ngokilo dipercaya mampu mengobati penyakit diabetes militus. Penelitian terdahulu menjelaskan bahwa ekstrak daun keji beling dapat menurunkan kadar glukosa darah. Tujuan dari penelitian ini adalah untuk mengetahui Potensi Ekstrak Etanol Daun Ngokilo (Stachytarpheta mutabilis, Vahl ) sebagai Penurun Kadar Glukosa Darah pada Tikus Putih (Rattus norvegicus). Pengujian dilakukan dengan metode eksperimen menggunakan mencit (Rattus norvegicus) jantan strain Swiss Webster usia 2-3 bulan dengan barat badan 30-40 gram sebagai hewan uji. Penelitian ini menggunakan empat perbandingan dosis ekstrak daun ngokilo yakni 1:10:30:50 dan kontrol menggunakan aguadest. Hasil penelitian menunjukkan bahwa ekstrak etanol daun ngokilo mempunyai nilai F Hitung 27.907 > F Tabel 2.60. Hal ini menunjukkan bahwa variable bebas (perbedaan konsentrasi ekstrak etanol daun ngokilo) terbukti berpengaruh secara signifikan terhadap variabel terikat (kadar gula darah). Artinya ekstrak daun ngokilo mempunyai efektivitas dalam menurunkan kadar gula darah mencit.
\end{abstract}

\section{Kata kunci : Diabetes Militus, Ekstrak Daun Ngokilo}

Abstract: Diabetes is a disease where the sufferer's body cannot control the level of sugar (glucose) in his blood. Diabetics cannot produce sufficient amounts of insulin or the body is unable to use insulin effectively, resulting in excess sugar in the blood. The chronic excess sugar blood (hyperglycemia) is toxic to the body. Ngokilo plants are believed to be able to treat diabetes mellitus. Previous studies have explained that the extract of kejibeling leaves can reduce blood glucose levels. The purpose of this study is to find out conducted research about on the potential of ethanol extract of Ngokilo leaves (Stachytarpheta mutabilis, Vahl) as a blood glucose level reduction in white rats (Rattus norvegicus). Tests carried out by an experimental method using mice (Rattus norvegicus) male Swiss Webster strain aged 2-3 months with west body 30-40 grams as a test animal. This study uses four dose ratio ngokilo leaf extracts namely 1: 10:30:50 and control using aquadest. The results showed that the ethanol extract of Ngokilo leaves had an F value of $F$ Tabel $2.60>$ F Table 2.60. This shows that the independent variable (differences in the concentration of the ethanol extract of ngokilo leaves) has been shown to significantly influence the dependent variable (blood sugar level). This means that the ethanol extract of Ngokilo leaves has effectiveness in reducing blood sugar levels in mice. 


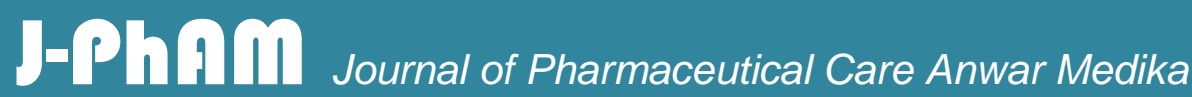

\section{Artikel Penelitian}

\section{Keywords: Diabetes Militus, Ethanol Extract Ngokilo Leaves}

\section{PENDAHULUAN}

Diabetes adalah suatu penyakit, dimana tubuh penderitanya tidak bisa secara otomatis mengendalikan tingkat gula (glukosa) dalam darahnya. Pada tubuh yang sehat, pankreas melepas hormon insulin yang bertugas mengangkut gula melalui darah ke otototot dan jaringan lain untuk memasok energi. Diabetes merupakan gangguan metabolisme dari distribusi gula oleh tubuh. Penderita diabetes tidak bisa memproduksi insulin dalam jumlah yang cukup atau tubuh yang tak mampu menggunakan insuin secara efektif, sehingga terjadilah kelebihan gula di dalam darah. Kelebihan gula yang kronis di dalam darah (hiperglikemia) ini menjadi racun bagi tubuh.

Apabila dibiarkan tak terkendali, kondisi diabetes ini dapat menimbulkan komplikasi penyakit yang berakibat fatal, seperti kerusakan saraf (Neuropathy), otak (cerebrovaskular), gangguan mata (retinopathy), penyakit jantung (kardiovaskular), penyakit ginjal (nefropathy), impotensi, gangguan pencernaan, komplikasi di mulut (gigi mudah lepas), mudah terinfeksi, kelainan kulit (gatal-gatal biasanya di sekitar kemaluan) dan luka membusuk (gangren).

Penyebab penyakit diabetes militus diabetes bisa kambuh karena disebabkan oleh makanan dan juga dari kebisaan yang sering dilakukan dalam kehidupan sehari hari, konsumsi makanan dan minuman yang mengandung banyak gula atau glukosa, bahkan makanan tidak sehat lainnya seperti mengandung banyak lemak. Karena pola makan yang tidak teratur dan asupan akanan yang masuk memicu kenaikan gula darah sehingga diabetes bisa kambuh.

Sudah banyak pengobatan yang dilakukan untuk menyembuhkan penyakit diabetes terutama diabetes jenis 2. Mulai dari penggunaan obat obatan kimia hingga pengobatan herbal yakni dengan menggunakan tanaman, misalnya mengkudu dan kulit manggis. Pengobatan dengan bahan kimia sudah pasti banyak efek sampingnya yang justru memberikan banyak efek negatif. 


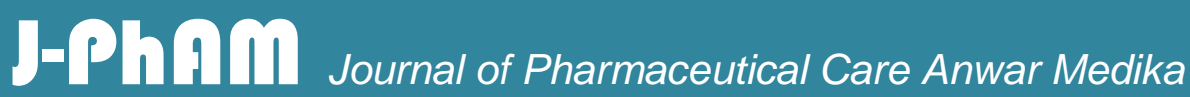

\section{Artikel Penelitian}

Maka yang bisa kita lakukan saat ini adalah selain melakukan tindakan prefentif seperti berolahraga teratur, minum air yang banyak, mengurangan makanan yang mengandung glukosa tinggi juga melakukan tindakan kuratif melalui pengobatan herbal. Pengobatan herbal dipercaya memberikan kasiat yang baik dan tanpa efek samping.

Sejauh ini masih belum banyak yang mengetahui kasiat tanaman ngokilo untuk pengobatan diabetes militus. Terlebih lagi tanaman ini merupakan tanaman liar yang jarang diperhatikan keberadaanya oleh masyarakat. Tanaman ngokilo termasuk jenis tumbuhan yang mudah berkembang biak ditanah subur, agak terlindung dan ditempat terbuka. Tanaman ngokilo mempunyai kasiat yang luar biasa untuk berbagai jenis penyakit antara lain ambeien, terkena bisa ular dan juga pengobatan penyakit diabetes militus tipe dua. Akan tetapi belum banyak penelitian yang menguji bahan yang terkandung didalam tanaman ngokilo tersebut. Hal ini merupakan daya tarik tersendiri bagi peneliti untuk melakukan uji laboratorium untuk mengetahui kandungan dari tanaman ngokilo.

Dari latar belakang diatas peneliti tertarik untuk melakukan penelitian dengan judul Efektifitas Ekstrak Daun Ngokilo (Stachytarpheta mutabilis, Vahl) terhadap Penyakit Diabates Militus Tipe 2.

\section{METODE PENELITIAN}

Metode penelitian yang dilakukan pada penelitian ini adalah metode eksperimen. Metode eksperimental merupakan metode penelitian yang memungkinkan peneliti memanipulasi variabel dan meneliti akibat-akibatnya. Pada metode ini variabel-variabel dikontrol sedemikian rupa, sehingga variabel luar yang mungkin mempengaruhi dapat dihilangkan (Hasan, 2002). Penelitian ini menggunakan bahan dasar daun ngokilo yang dijadikan ekstrak untuk mengobati penyakit diabetes melittus.

\section{Desain penelitian}

Bagan tahapan pembuatan dan aplikasi ekstrak daun ngokilo dapat dilihat pada gambar 1. 


\section{Artikel Penelitian}

Gambar 1. Bagan Tahapan Pembuatan dan aplikasi ekstrak daun ngokilo

a. Pembuatan Ekstrak Daun Ngokilo

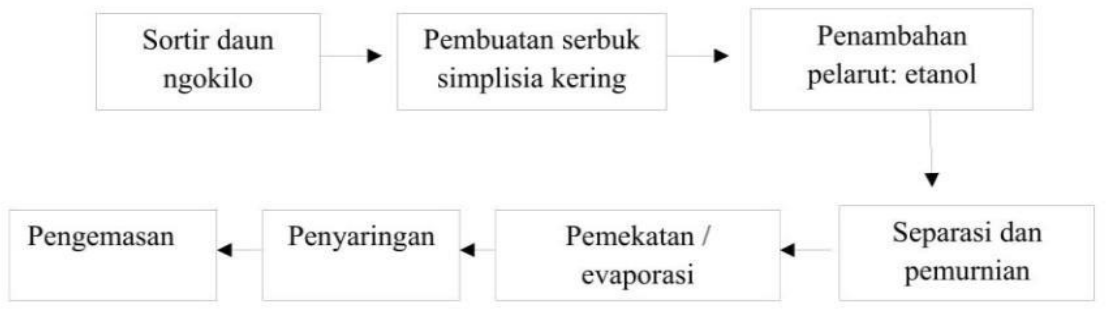

b. Aplikasi Ekstrak Daun Ngokilo

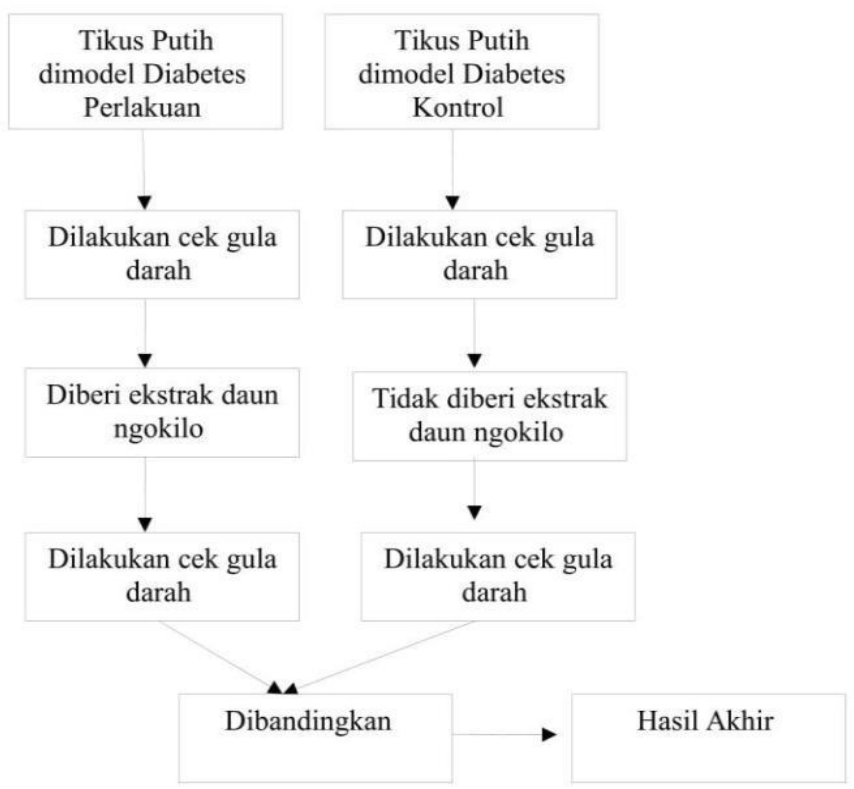

\section{TAHAPAN PENELITIAN}

\section{Subyek Penelitian}

Subyek dalam penelitian ini adalah Mencit (Mus musculus) jantan strain Swiss Webster sejumlah 40 ekor berumur 2-3 bulan dengan berat 20-30 gram dan dibagi kedalam 8 (delapan) kelompok perlakuan dan 5 (lima) kali ulangan serta diletakkan dalam kandang yang alasnya telah dilapisi dengan sekam padi. Sebelumnya mencit diadaptasi selama 8 hari dengan diberi makan dan minum setiap hari. Mencit yang diguanakan adalah mencit dengan kadar gula darah yang tinggi (>124 mg/dl) yaitu mencit normal yang di induksi aloksan agar meningkat kadar gula darahnya. Masing-masing kandang diberi label sesuai dengan jumlah perlakuan. 


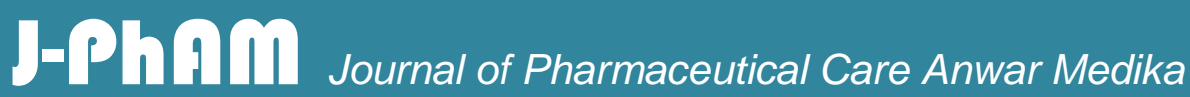

\section{Artikel Penelitian}

Mencit diberi makan berupa pellet ayam yang dicampur dengan nasi dan diberi air minum. Pengujian terhadap hewan model mencit (Mus musculus) strain Swiss Webster dilakukan di Laboratorium terpadu Tecnopark Universitas Islam Lamongan. Penelitian ini dilakukan pada bulan Juni- Juli 2019.

\section{Cara Pengambilan Simplisia}

Daun Ngokilo (Stachytarpheta mutabilis, Vahl) diperoleh dari tanaman liar yang berada dipinggir jalan di desa Jagran Kecamatan Karannggeneng Lamongan. Persiapan pembuatan ekstrak dengan mengambil daun ngokilo yang masih segar sebanyak $3 \mathrm{~kg}$, dicuci bersih, ditiriskan kemudian dikeringkan. Proses ekstraksi daun ngokilo dilakukan di laboratorium terpadu Tecnopark Universiotas Islam Lamongan.

\section{Persiapan Ekstraksi Daun Ngokilo}

Daun ngokilo (Stachytarpheta mutabilis, Vahl) yang sudah kering di blender kemudian di ayak lalu dilakukan maserasi dengan menambahkan larutan etanol dan direndam selama 24 jam. Kemudian disaring dengan menggunakan kertas saring untuk mendapatkan filtratnya, reduksi larutan dimaserasi kembali sebanyak 2 (dua) kali sampai diperoleh larutan jernih. Selanjutnya dilakukan pemekatan dengan cara penguapan/evaporasi cairan pelarut tapi tidak sampai pada kondisi kering, hanya sampai diperoleh ekstrak kental/pekat/. Selanjutnya dihitung dosis yang akan diberikan yaitu P1 (4.5 mg/40 grBB dalam 0.4 akuades), P2 (45 mg/40 grBB dalam 0.4 akuades), P3 (135 mg/40 grBB dalam 0.4 akuades), P4 (225 mg/40 grBB dalam 0.4 akuades), dan K (0.4 cc akuades).

\section{Perlakuan Hiperglikemia Mencit (Mus musculus) Jantan Strain Swiss Webster}

Mencit diinjeksi intraperitonial dengan aloksan monohidrat dosis $130 \mathrm{mg} / \mathrm{kgBB}$ dengan volume penyuntikan $0.5 \mathrm{ml} . \mathrm{kg}$ sebanyak 2 kali. Selama induksi dengan aloksan mencit tetap diberi makan dan minum. Kemudian diperiksa kadar gula darahnya. 


\section{Artikel Penelitian}

\section{Cara Pengukuran Kadar Glukosa Darah Mencit (Mus musculus) Jantan strain Swiss} Webster

Pengukuran kadar glukosa darah mencit (Mus musculus) jantan strain Swiss Webster dilakukan dengan Glukometer kit. Alat ini bekerja secara elektrokimia berdasarkan pengukuran potensial (daya listrik) yang disebabkan oleh reaksi dari glukosa dengan bahan pereaksi glukosa pada elektroda strip pada alat glucometer kit. Pengukuran kadar glukosa darah dilakukan pada hari ke 7, hari ke 12 dan hari ke 18. Sebelum diberi perlakuan, terlebih dahulu dilakukan pengukuran kadar gula darah awal pada mencit (Mus musculus) jantan strain Swiss Webster. Setelah setelah itu dinaikan kadar gula darahnya dengan menggunakan aloksan. Baru kemudian dilakukan pemberian ekstrak etanol duan ngokilo selama 6 (enam) hari secara peroral setiap hari. Kemudian pada hari ke 7 setelah perlakauan, diukur kembali kadar gula darah sebagai kadar gula darah akhir.

\section{Teknik Pengumpulan dan Analisis Data}

Teknik pengumpulan dan analisis data diperoleh dengan beberapa macam pengujian:

1. Uji pH dilakukan dengan melarutkan ekstrak daun ngokilo diencerkan menggunakan aquadest kemudian diukur dengan $\mathrm{pH}$ meter.

2. Aplikasi ekstrak kental etanol daun ngokilo terhadap mencit (Mus musculus) yang dijadikan yang dibagi dalam dua perlakuan Mencit yakni dibuat model diabetes dan kelompok kontrol yakni mencit (Mus musculus) tanpa dibuat model diabetes dan hanya diberi akuades saja.

3. Pengamatan perubahan kadar gula dalam darah. Proses ini diawali dengan melakukan tes kadar gula darah sebelum dilakukan perlakuan dengan menggunakan ekstrak daun ngokilo. Selanjutnya Mencit diberi ekstrak daun ngokilo setiap hari secara teratur.

Selanjutnya dilakukan pengecekan kadar gula darah akhir.

Analisis data dilakukan dengan menggunakan ANAVA satu arah dengan tingkat kepercayaan 95\% untuk mengetahui apakah masing-masing perlakuan yang diberikan mempunyai pengaruh yang signifikan dalam penurunan kadar gula darah mencit (Mus musculus) jantan strain Swiss Webster. Selanjutnya dilakukan uji T-Paired dengan tingkat kepercayaan $95 \%$ untuk mengetahui perbedaan kadar gula darah antara sebelum perlkuan dan sesudah perlakuan. 


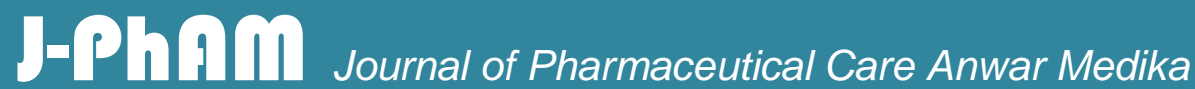

Artikel Penelitian

HASIL DAN PEMBAHASAN

Formulasi Dosis Ekstrak Kental Daun Ngokilo (Stachytarpheta mutabilis, Vahl)

Pemberian dosis ekstrak daun ngokilo yang diberikan pada mencit menyesuaikan dengan berat badan mencit. Mencit yang digunakan sebagai model adalah mencit jantan strain Swiss Webster usia 2-3 bulan dengan barat badan 30-40 gram. Perbandingan perlakuan 0:1:10:30:50. Pada penelitian ini ekstrak etanol daun ngokilo diberikan secara oral, sehingga persen pemberian ekstrak digunakan 1\%. Menurut Yorijuli (2012) pemberian ekstrak ditentukan berdasarkan rute pemberian obat yang akan digunakan yakni rute oral/oral gavage/gastric intubation diberikan sebesar $1 \%$, rute intraperitoneal sebesar $0.1 \%$ dan rute intravena sebesar $0,1 \%$.

Mencit yang digunakan dengan berat badan berkisar antara 30-40 gram. Sehingga rumus penghitungan adalah :

Volume Dosis : Berat Mencit x Persen Pemberian

$=40$ gram $\times 1 \%$

$=0.4 \mathrm{ml}$

Menurut Sa'roni dan Wahjoedi (2002), perlakuan yang diberikan pada tikust yaitu sebagai berikut:

1. Kelompok A: kontrol dengan diberi akuades $1 \mathrm{ml} / 100 \mathrm{gBB}$

2. Kelompok B: diberi ekstrak dengan dosis 11, $25 \mathrm{mg} / 100 \mathrm{gBB}$ dalam $1 \mathrm{ml} / 100 \mathrm{gBB}$

3. Kelompok C: diberi ekstrak dengan dosis 112,5 mg/100 gBB dalam $1 \mathrm{ml} / 100 \mathrm{gBB}$

4. Kelompok D: diberi ekstrak dengan dosis 337,5 mg/100 gBB dalam $1 \mathrm{ml} / 100 \mathrm{gBB}$

Dosis yang digunakan untuk mencit 11,25 mg/100 gBB dalam $1 \mathrm{ml} / 100 \mathrm{gBB}$ artinya dosis yang diberikan setiap per gram badan tikus adalah

$=11.25 \mathrm{mg} / 100 \mathrm{~g}=0.1125 \mathrm{gram}$

Maka, karena mencit yang digunakan berukuran 40 gram, maka dosis per gram berat badan mencit $\mathrm{x}$ berat badan mencit

$=0.1125$ gram $\mathrm{x} 40$ gram

$=4.5$ gram

Perlakuan yang digunakan dalam penelitian ini menggunakan perbandingan 1:10:30:50:

Maka penghitungan dosisnya adalah sebagai berikut: 


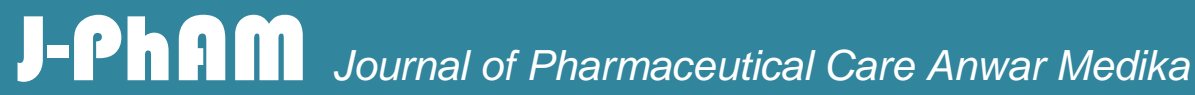

\section{Artikel Penelitian}

1. Perlakuan $1: \mathrm{P} 1=4.5$ gram $\mathrm{x} 1=4,5 \mathrm{mg}$

2. Perlakuan $2: \mathrm{P} 2=4.5$ gram $\times 10=45 \mathrm{mg}$

3. Perlakuan $3: \mathrm{P} 4=4.5$ gram $\times 30=135 \mathrm{mg}$

4. Perlakuan $4: \mathrm{P} 6=4,5$ gram $\times 50=225 \mathrm{mg}$

Dengan demikian formulasi dosis ekstrak etanol daun ngokilo dapat dilihat dalam Tabel 1.

Tabel 1. Formulasi Dosis Ekstrak Etanol Daun Ngokilo (Stachytarpheta mutabilis, Vahl)

\begin{tabular}{|c|c|c|}
\hline Perlakuan & Dosis & Jum lah Mencit \\
\hline K & $0.4 \mathrm{ml}$ akuades & 5 \\
\hline P1 & $4.5 \mathrm{mg} / 40$ grBB dalam 0.4 akuades & 5 \\
\hline P10 & $45 \mathrm{mg} / 40$ grBB dalam 0.4 akuades & 5 \\
\hline P30 & $135 \mathrm{mg} / 40$ grBB dalam 0.4 akuades & 5 \\
P50 & $225 \mathrm{mg} / 40$ grBB dalam 0.4 akuades & 5 \\
\hline
\end{tabular}

Perlakuan yang digunakan menggunakan dosis mulai 1 hingga 60 diharapkan bisa memberikan gambaran yang signifikan terkait dengan pengaruh dari ekstrak etanol daun ngokilo dalam menurunkan kadar gula darah didalam tubuh mencit.

\section{Uji Derajat Keasaman (pH)}

Uji pH yang dilakukan menghasilkan tabel 2 .

Tabel 2. Uji pH Ekstrak Kental Daun Ngokilo (Stachytarpheta mutabilis, Vahl) pada Masing-Masing Perlakuan

\begin{tabular}{|c|c|c|}
\hline No & Dosis & $\mathbf{p H}$ \\
\hline $\mathbf{1}$ & $0.4 \mathrm{~m} 1$ akuades & 7 \\
\hline $\mathbf{2}$ & $4.5 \mathrm{mg} / 40 \mathrm{grBB}$ dalam 0.4 akuades & 7 \\
\hline $\mathbf{3}$ & $45 \mathrm{mg} / 40 \mathrm{grBB}$ dalam 0.4 akuades & 7 \\
\hline $\mathbf{4}$ & $135 \mathrm{mg} / 40 \mathrm{grBB}$ dalam 0.4 akuades & 7 \\
\hline $\mathbf{5}$ & $225 \mathrm{mg} / 40 \mathrm{grBB}$ dalam 0.4 akuades & 7 \\
\hline
\end{tabular}




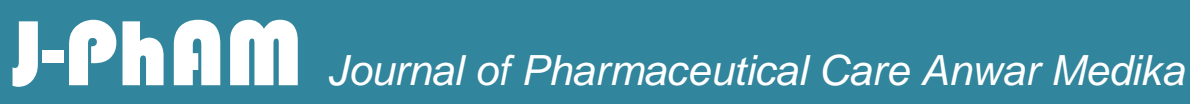

\section{Artikel Penelitian}

Uji $\mathrm{pH}$ dilakukan untuk keamanan produk tersebut ketika digunakan. Derajat keasaman $(\mathrm{pH})$ merupakan pengukuran aktivitas hidrogen dalam lingkungan air. Berdasarkan pemberitaan dari Medicine.net menyatakan bahwa $\mathrm{pH}$ tubuh dalam keadaan normal idelanya berkisar pada rentang netrak-cenderung basa, yaitu sekitar 7,35 sampai 7,45. Kadar $\mathrm{pH}$ yang kurang dari 7 dikatakan bersifat asam dan jika lebih dari 7 sudah tergolong basa. Tubuh menjaga kadar $\mathrm{pH}$ dengan bantuan ginjal dan paru-paru untuk mengatur kadar bikarbonat. Bikarbonat digunakan sebagai pelindung jika tiba-tiba $\mathrm{pH}$ mengalami perubahan. Kadar $\mathrm{pH}$ tubuh sebaiknya harus selalu berada dalam rentang yang idela. Jika cairan dalam tubuh terlalu asam atau terlalu basa, akan berdampak pada fungsi organ tubuh dan kerja metabolism tubuh (Setiaji, W: 2018).

Berdasarkan hasil percobaan mulai dari perlakuan 1 hingga 4 dan kontrol didapat bahwa pH ekstrak daun ngokilo adalah 7 yakni netral. Hal ini menunjukan bahwa kondisi ekstrak aman dan baik digunakan sebagai obat untuk menurunkan kadar gula darah dalam mencit yang sudah di induksi aloksan. Seperti kita ketahui bersama bahwa $\mathrm{pH}$ normal untuk tubuh berkisar antara 7,35 sampai 7,45 sehingga ekstrak daun ngokilo yang diaplikasikan pada mencit tidak akan memberikan efek yang negatif bagitu tubuh karena terlalu asam atau terlalu basa.

\section{Aplikasi Ekstrak Daun Ngokilo}

Nilai rata-rata kadar gula darah mencit diabetes mellitus yang diinduksi aloksan setelah pemberian ekstrak etanol daun ngokilo (Stachytarpheta mutabilis, Vahl) selama 7 hari dapat dilihat pada tabel 3.

Tabel 3. Penurunan Kadar Glukoa Mencit diabetes mellitus (Mus musculus) Jantan Strain Swiss Webster yang diinduksi Aloksan pada 8 (delapan) kelompok perlakuan

\begin{tabular}{|l|r|r|r|}
\hline Kelompok & Kadar Glukosa Kadar Glukosa Sebelum & \multicolumn{1}{|c|}{ Kadar Glukosa } \\
\hline Perlakuan & Awal (mg/dl) & Perlakuan (mg/dl) & \multicolumn{1}{c|}{ Setelah Perlakuan } \\
\hline & & & (mg/dl) \\
\hline K & 100,4 & 100,2 & 100,4 \\
\hline P1 & 107 & 147,8 & 145,2 \\
\hline P10 & 99,4 & 146,6 & 140,6 \\
P30 & $\mathbf{9 2 , 6}$ & $\mathbf{1 4 2 , 6}$ & $\mathbf{1 1 0 , 6}$ \\
\hline P50 & 95 & 137 & 96,8 \\
\hline
\end{tabular}




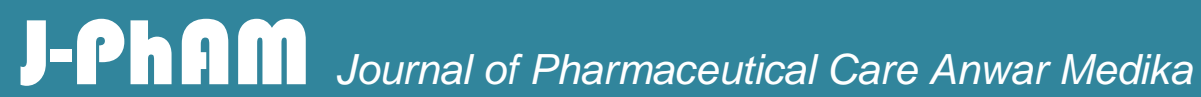

\section{Artikel Penelitian}

Nilai rata-rata kadar gula darah mencit diabetes mellitus yang diinduksi aloksan setelah pemberian ekstrak etanol daun ngokilo (Stachytarpheta mutabilis, Vahl) selama 7 hari mengalami penurunan yang signifikan pada masing-masing perlakuan dibandingkan dengan kontrol. Penurunan kadar glukosa darah mencit yang paling rendah didapatkan pada kelompok P1 yakni perlakuan dengan pemberian ekstrak etanol daun ngokilo dosis 4.5 mg/40 grBB dalam 0.4 akuades yakni terjadi penurunan dari kadar gula darah sebesar 147,8 menjadi 145,2. Kelompok P2 yakni 45 mg/40 grBB dalam 0.4 akuades terjadi penurunan 146,6 mg/dl menjadi 140,6 mg/dl. Kelompok P3 dosis 135 mg/40 grBB dalam 0.4 akuades terjadi penurunan kadar gula darah dari 142,6 mg/dl menjadi 110,6 mg/dl. Kelompok P4 dosis $225 \mathrm{mg} / 40$ grBB dalam 0.4 akuades terjadi penurunan kadar gula darah dari $137 \mathrm{mg} / \mathrm{dl}$ menjadi 96,8 mg/dl. Kelompok kontrol yang diberi akuades sebanyak 0,4 cc mengalami peningkatan sedikit kadar gula darahnya.

Hal ini sejalan dengan penelitian yang dilakukan oleh Nurhidayah dkk (2015) yang menyatakan bahwa ekstrak daun keji beling dengan dosis uji yang digunakan dapat menurunkan kadar glukosa darah pada tikus putih. Penentuan dosis terbaik dilakukan untuk mengetahui dosis uji mana yang paling baik dalam menurunkan kadar glukosa darah dengan parameter waktu yang paling cepat dalam menurunkan kadar glukosa tersebut

Data perbedaan kadar glukosa darah antara sebelum diberi ekstrak daun ngokilo dan sesudah diberi ekstrak daun ngokilo dapat dilihat pada Gambar 2.

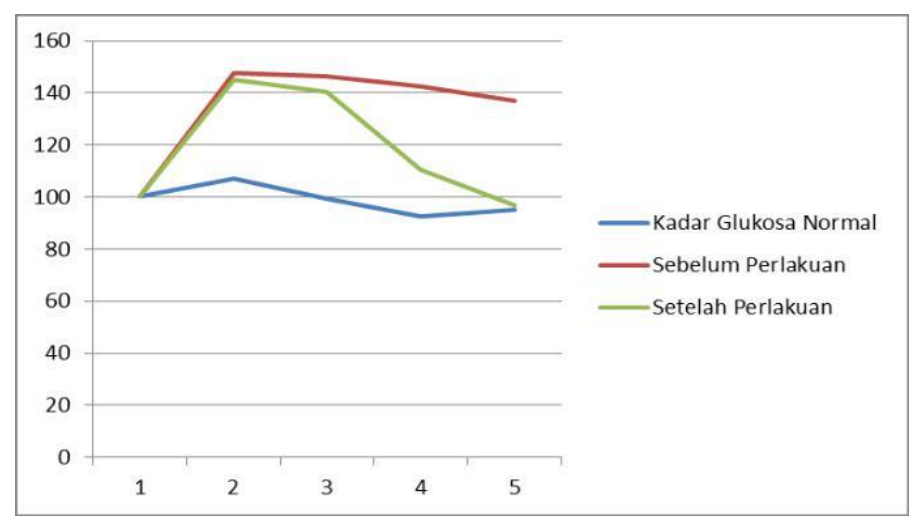

Gambar 2. Grafik perbandingan kadar gula darah sebelum dan sesudah diberi perlakuan 


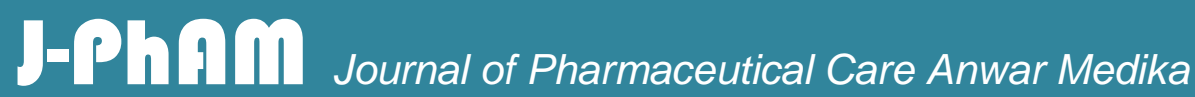

\section{Artikel Penelitian}

Dari grafik perbandingan kadar gula darah diatas dapat diketahui bahwa penurunan kadar glukosa darah yang paling rendah terjadi pada kelompok perlakuan 1 yakni pada dosis $4.5 \mathrm{mg} / 40$ grBB, terjadi penurunan kadar gula darah dari 147,8 mg/dl menjadi 145,2 $\mathrm{mg} / \mathrm{dl}$. Penurunan kadar glukosa darah yang paling tinggi terjadi pada dosis $225 \mathrm{mg} / 40$ grBB dalam 0.4 akuades, dapat kita lihat kadar glukosa darah sebelum pemberian ekstrak etanol daun ngokilo adalah $137 \mathrm{mg} / \mathrm{dl}$ dan setelah diberi ekstrak etanol daun ngokilo menjadi $96.8 \mathrm{mg} / \mathrm{dl}$. Hal ini sesuai dengan penelitian yang dilakukan oleh Nurhidayah (2015) menjelaskan bahwa adanya kesamaan dalam penurunan kadar glukosa darah yang ditunjukkan ektrak daun geji beling dapat menurunkan kadar glukosa pada menit ke 45 .

Dapat dijelaskan bahwa pada dosis yang lebih tinggi mengandung senyawa aktif yang lebih banyak sehingga dapat mencegah peningkatan kadar glukosa darah lebih besar. Hal ini sejalan dengan penelitian yang dilakukan oleh Sofia, Rinidar dan Mariana bahwa pemberian ekstrak daun sambung nyawa dosis tunggal dari $100 \mathrm{mg} / \mathrm{kgBB}, 150 \mathrm{mg} / \mathrm{kgBB}$ dan $200 \mathrm{mg} / \mathrm{kgBB}$ dapat menurunkan kadar gula darah pada mencit diabetes mellitus.

Dari data yang diperoleh kemudian dianalisis menggunakan uji Anova One Way untuk mengetahui apakah terdapat perbedaan secara signifikan setiap dosis yang berbeda dalam mempengaruhi penurunan kadar glukosa darah mencit. Hasil uji ANOVA dapat dilihat pada tabel 4. Berdasarkan hasil uji ANAVA One Way didapatkan adanya perbedaan yang signifikan antar kelompok perlakuan ( $\mathrm{F}$ hitung 27,907 > F tabel 2,60). Hal ini menunjukan bahwa terdapat perbedaan yang signifikan kadar gula darah mencit pada tiaptiap perlakuan.

Tabel 4. Hasil uji ANOVA terhadap warna Cream

\begin{tabular}{|c|c|c|c|c|c|}
\hline \multicolumn{6}{|c|}{ KADAR_GULA_DARAH } \\
\hline & Sum of Squares & df & Mean & $\mathrm{F}$ & Sig. \\
\hline & & & Square & & \\
\hline Between Groups & 10309.840 & 4 & 2577.460 & 27.907 & .000 \\
\hline Within Groups & 1847.200 & 20 & 92.360 & & \\
\hline Total & 12157.040 & 24 & & & \\
\hline
\end{tabular}




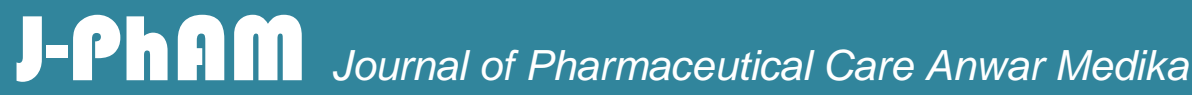

\section{Artikel Penelitian}

Selain uji ANOVA, dilakukan uji $\mathrm{T}$ paired untuk mengetahui ada tidaknya perbedaan kadar gula darah pada mencit antara sebelum dan sesudah diberi perlakuan ekstrak daun ngokilo. Data hasil uji T paired dapat dilihat pada tabel 5. Uji T Paired dimaksudkan untuk mengetahui perbedaan kadar glukosa darah mencit antara sebelum dan sesudah pemberian ekstrak daun ngokilo. Berdasarkan hasil analisis menggunakan uji T Paired Dimana nilai T Hitung sebesar $(4,505)$ dengan taraf kepercayaan 5\% lebih besar dari pada $\mathrm{T}$ tabel yakni sebesar $(1,71)$. Berdasarkan data tersebut dapat ditarik kesimpulan bahwa terdapat perbedaan signifikan kadar glukosa darah antara sebelum dan sesudah diberi ekstrak daun ngokilo.

Tabel 5. Uji T-Paired pada Kadar Glukosa Darah sebelum dan sesudah Diberi Ekstrak Daun Ngokilo

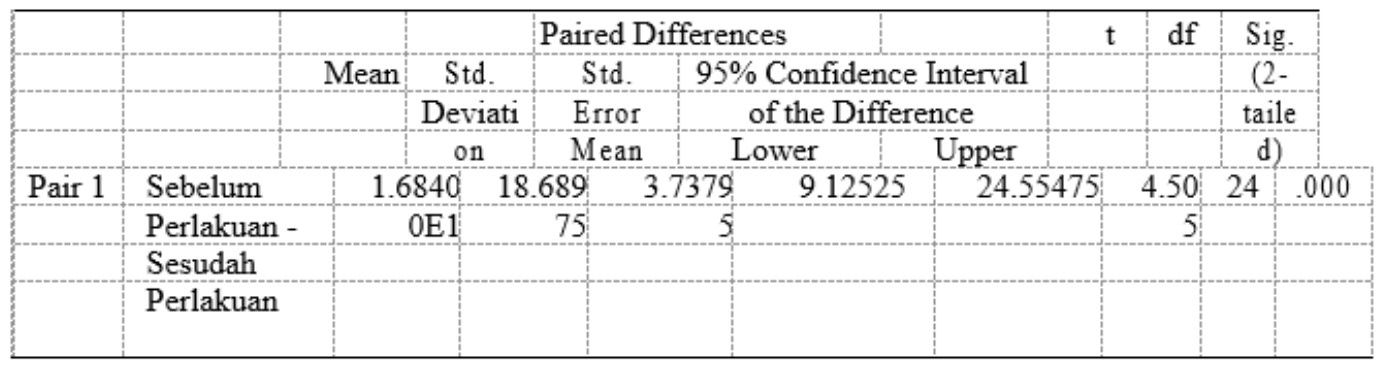

Penurunan kadar gula darah pada mencit diabetes yang di induksi dengan menggunakan aloksan setelah pemberian ekstrak etanol daun ngokilo dapat mencegah kerusakan sel-sel beta pulau Langerhans oleh kandungan bahan-bahan aktif ekstrak etanol daun ngokilo yang bersifat antidiabetes seperti steroid, triterpenoid, dan protein. Bahan aktif triterpenoid pada tanaman daun ngokilo diketahui memiliki berbagai efek farmakologis diantaranya dapat menurunkan kadar gula darah (antidiabetik), antiradang, merangsang daya tahan sel, penghambat reaksi imunitas dan antihistamin.

Ektrak daun ngokilo juga mengandung senyawa alkaloid dan flavonoid yang bersifat sebagai antioksidan yang dapat menekan aktivitas radikal bebas. Flavonoid bekerja dengan cara menghambat encim alfa amylase dan alfa glukosidase yang berfungsi menguraikan karbohidrat menjadi monosakarida yang dapat diserap oleh usus. 


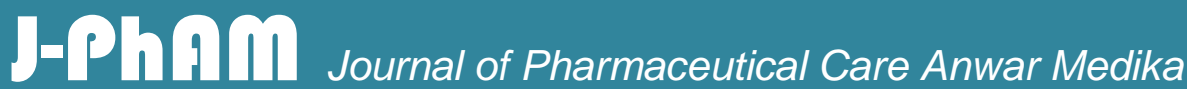

\section{Artikel Penelitian}

Dengan demikian kadar gula darah tidak meningkat setelah mengkonsumsi makanan atau minuman yang mengandung gula atau senyawa yang dapat dipecah menjadi gula. Efek inilah yang diduga dapat menurunkan kadar gula darah pada penderita penyakit diabetes mellitus.

\section{KESIMPULAN}

Dari percobaan Potensi Ekstrak Etanol Daun Ngokilo (Stachytarpheta mutabilis, Vahl) terhadap penurunan kadar glukosa darah pada tikus putih (Rattus norvegicus) dapat ditarik kesimpulan bahwa:

1.Terdapat 4 dosis perlakuan yakni $4.5 \mathrm{mg} / 40$ grBB dalam 0.4 akuades, $45 \mathrm{mg} / 40 \mathrm{grBB}$ dalam 0.4 akuades, $135 \mathrm{mg} / 40$ grBB dalam 0.4 akuades, $225 \mathrm{mg} / 40$ grBB dalam 0.4 akuades dan kontrol dengan menggunakan $0.4 \mathrm{ml}$ akuades.

2.Uji derajat keasaman $(\mathrm{pH})$ ekstrak etanol daun ngokilo dihasilkan $\mathrm{pH}$ normal yakni 7 sehingga aman diaplikasikan pada tubuh mencit.

3.Aplikasi Ekstrak daun ngokilo menghasilkan perbedaan kadar gula darah yang signifikan, dari ke empat dosis perlakuan, yang paling baik adalah P50, yakni dengan kadar glukosa awal $137 \mathrm{mg} / \mathrm{dl}$ menjadi $96,8 \mathrm{mg} / \mathrm{dl}$

4.Uji ANAVA One Way didapatkan nilai F hitung sebesar 27,907 lebih besar daripada F tabel yakni 2.60, artinya terdapat perbedaan yang signifikan kadar gula darah mencit pada tiap-tiap perlakuan

5.Uji T Paired menunjukkan T Hitung sebesar 4.505 > dari pada T Tabel sebesar 1.71, artinya terdapat perbedaan signifikan kadar gula darah antara sebelum dan sesudah perlakuan

\section{UCAPAN TERIMA KASIH}

1. Terimakasih kepada Allah SWT yang telah memberikan karuniaNya kepada kita semua. Selanjutnya kami ucapkan terimakasih kepada DPRM Kemenristekdikti yang telah memberikan kesempatan kepada kami untuk melaksanakan penelitian melalui pemberian dana Hibah Penelitian Skema Penelitain Dosen Pemula. 


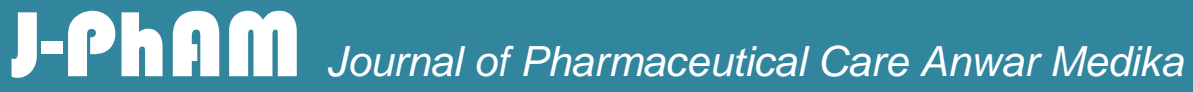

\section{Artikel Penelitian}

2. Ucapan terimakasih selanjutnya kami sampaikan kepada Lembaga Penelitian, Pengebangan dan Pengabdian Masyarakat (LITBANGPEMAS) Universitas Islam Lamongan yang telah memberikan wadah dan kesempatan untuk melaksanakan kegiatan penelitian.

3. Terimakasih banyak kepada suami dan keluarga atas segala doa dan dukungannya untuk semua kegiatan kegiatan yang insyallah positif untuk saya, keluarga dan masyarakat secara umum. 


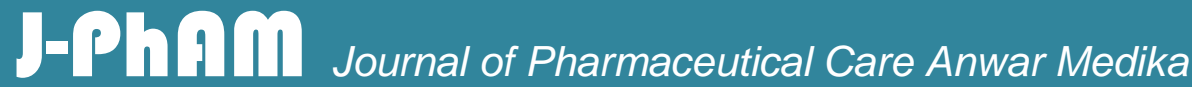

Artikel Penelitian

\section{DAFTAR PUSTAKA}

1. Diabetes Melitus. https://id.wikipedia.org/wiki/Diabetes_melitus. diakses pada tanggal 10 April 2017

2. Manfaat dan Kasiat Tanaman Ngokilo.

http://tanamanherbal.blogspot.co.id/2015/08/manfaat-dan-khasiat-tanamanngokilo.html. diakses pada tanggal 10 April 2017

3. Manfaat Tanaman Keji Beling.

https://obatherbalnusantara.wordpress.com/2012/04/01/manfaat-tanaman-keji-belingbagi-kesehatan/. Diakses pada tanggal 10 April 2017

4. Agustina, Tri ,2009.Gambaran Sikap Pasien Diabetes Melitus Di Poli Penyakit Dalam Rsud Dr.Moewardi Surakarta Terhadap Kunjungan Ulang Konsultasi Gizi. KTI D3. Fakultas Ilmu Kesehatan Universitas Muhammadiyah Surakarta, Surakarta.

5. Herman, 2014. "Komplikasi Penyakit yang Mengintai Penderita Diabetes" Jakarta.

6. Irdalisa, dkk (2015), Profil Kadar Glukosa Darah Pada Tikus Setelah Penyuntikan Aloksan Sebagai Hewan Model Hiperglikemik. Jurnal EduBio Tropika, Volume 3, Nomor 1, April 2015, hlm. 1-50

7. Mohjuarno.2009. Makalah Kontenporer Konsentrasi Epidemiologi Pasca Sarjana: Penanggulangan Diabetes Melitus. Makassar :Universitas Hasanuddin.

8. Murwani, Arita dan Afifin Sholeha, 2007. Pengaruh Konseling Keluarga Terhadap Perbaikan Peran Keluarga Dalam Pengelolaan Anggota Keluarga Dengan DM Di Wilayah Kerja Puskesmas Kokap I Kulon Progo 2007. Jurnal Kesehatan Surya Medika Yogyakarta. Ilmu Keperawatan Stikes Surya Global Yogyakarta.

9. Mustika, A, dkk (2017), Efek Ekstrak Daun Singawalang (Petiveria alliacea) dalam Menurunkan Kadar Glukosa Darah melalui Peningkatan Ekspresi AMPK- $\alpha 1$ pada Tikus Model Diabetes Melitus. Jurnal Farmasi Klinik Indonesia, Jurnal Farmasi Klinik Indonesia, Maret 2017, Vol. 6 No. 1, hlm 22-31, ISSN: 2252-6218.

10. Nonci, F,Y, dkk (2016), Uji Aktivitas Ekstrak Etanol Daun Kejibeling (Strobilanthes Crispus Linn) Terhadapa Penurunan Kadar Glukosa Darah Pada Mencit Jantan (Mus Musculus). JF FIK UINAM Vol.4 No.1 2016 


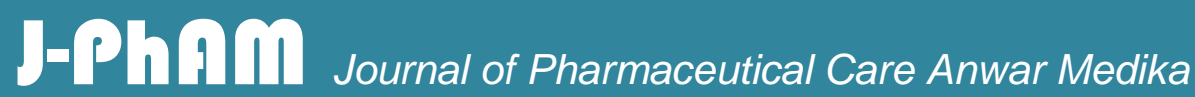

\section{Artikel Penelitian}

11. Nurhidayah, K dkk (2015), Potensi Ekstrak Daun Keji Beling (Strobilanthes Crispus) Sebagai Penurun Kadar Glukosa Darah: Uji In Vivo Pada Tikus Putih (Rattus Norvegicus). Prosiding Seminar Nasional Kefarmasian Ke-2, Samarinda, 24-25 Oktober 2015

12. Rakhmadany, dkk. 2010. Makalah Diabetes Melitus. Jakarta : Universitas Islam Negeri

13. Setiaji, B,R, (2018), Pentingnya Menjaga Kadar pH Tubuh Tetap Seimbang (Berapa pH Tubuh yang Ideal?) diakses dari https://hellosehat.com/hidup-sehat/fakta-unik/ph-tubuhideal-asidosis-alkalosis/ pada tanggal 12 Agustus 2019

14. Shahab, Alwi,2006.Diagnosis Dan Penatalaksanaan Diabetes Melitus (Disarikan Dari Konsensus Pengelolaan Diabetes Melitus Di Indonesia : Perkeni 2006).Subbagian Endokrinologi Metabolik, Bagian Ilmu Penyakit Dalam, Fk Unsri/ Rsmh Palembang, Palembang.

15. Soegondo S, Pradana S, Subekti I, et all, Petunjuk Praktis Pengelolaan Diabetes Melitus Tipe 2, PB PERKENI, Jakarta, 2003

16. Sofia, dkk (2011), Uji in Vivo Ekstrak Etanol Daun Sambung Nyawa (Gynura procumbens) Terhadap Penurunan Kadar Gula Darah Mencit (Mus musculus) Jantan Strain Swiss Webster Diabetes Mellitus. JURNAL KEDOKTERAN SYIAH KUALA Volume 11 Nomor 3 Desember 2011

17. Tanaman Ngokilo. http://www.pdpersi.co.id/content/news.php?catid=7\&mid=5\&nid=1124. Diakses pada tanggal 10 April 2017

18. Waspadji, Sarwono dkk., 2009. Pedoman Diet Diabetes Melitus. Jakarta: FKUI.

19.WHO, 1999. Defenition, Diagnosis and Classification of Diabetes Melitus and Its Complication. 